\title{
AUPF
}

\section{Best Practices in the Internationalization of Higher Education at Petra Christian University}

\author{
Djwantoro Hardjito ${ }^{a}$, Rolly Intan $^{\text {b) }}$ and Meilinda ${ }^{\text {c) }}$ \\ ${ }^{\text {a) }}$ Rector, ${ }^{\text {b) }}$ Former Rector, ${ }^{c}$ Former Head of International Office \\ Petra Christian University, Indonesia \\ Email: ${ }^{a)}$ jwwantoro.h@petra.ac.id
}

\section{Background}

Petra Christian University (PCU) is located in Surabaya, the second largest city in Indonesia. In its 57 years of age, PCU has been chosen as the Best Private University in Indonesia for the last three consecutive years from 2015-2017, by the Indonesian Ministry of Research, Technology and Higher Education. Currently, PCU has approximately 8700 students with about 320 full-time lecturers and professors.

With the vision to be a Caring and Global University with commitment to Christian values, and by providing holistic education, PCU graduates are expected to possess cultural excellence, alongside with academic, emotional, moral and spiritual excellences. In this regard, students should have opportunities to learn and to be engaged with other foreign cultures in order to prepare their roles in global era. With this in mind, PCU strives to place internationalization as one of its priorities. A number of initiatives and systems have been laid-down to foster the pace of internationalization at PCU.

\section{Best Practice of Internationalization}

Among the first milestones of internationalization at PCU was the signing of a Memorandum of Understanding (MOU) with the Dongseo University, Korea, back in 1996. The collaboration between these two universities was then implemented in the form ofCommunity Outreach Program (COP), organized by PCU, attended by students from both universities, to carry out a community service program in several villages in the East Java Province in Indonesia for the duration of three weeks. The COP program has since been organized as an annual event, and its scope widened to include students from many other universities from the Netherland, Japan, China, Taiwan, Hongkong, Singapore, and Australia.

COP has been developed to be an international service-learning program. Servicelearning is considered as the most powerful pedagogical method in holistic education. COP provides opportunity for students coming from various countries, cultures and backgrounds, to livetogether in local villagers' houses and to work together with the local people to carryout programs and activities suited to the need of the community. Concurrently, living and working together with the villagers enable students to learn from their wisdom as well. Attending COP has been a life changing experience for many students, not only in terms of experiencing internationalization at home for our students, but also inchanging their mindset and worldview after living and working together with fellow students coming from different countries and villagers, in a very different life conditions. Since 2014, COP has been expanded tobe organized also in Kupang, in the eastern part of Indonesia.

In 2011, PCU and Dongseo University initiated an annual international summer program, called Asia Summer Program (ASP). The first ASP was held successfullyin Surabaya, hostedby PCU,in 2012. Five universities, namely Dongseo University, University of Malaysia Perlis, Bangkok University, Josai University and PCUparticipated in the first ASP, and signed MOU together as the founders of ASP. All participating institutions send 


\section{AUPF}

their students to attend ASP. At the same time, theyalso send their lecturers and professorsto teachvariousclasses. Through ASP, students may learn everything (culture, economics, and politics) about Asia as the biggest and the most powerful continent in the world in terms of region, population and economy. Since ASP was accepted as an official program of the Asia University Presidents Forum (AUPF) in AUPF 2012, it has been successfully growing in the number of participants and partner institutions. The host of ASP is expected to alternate among every Asian country in order to give more experience for students and lecturers to learn and to engage with other cultures. As the result, six ASPs have been successfully organized since 2012 by six different universities in six different countries of Asia as follows:

- The $1^{\text {st }}$ ASP 2012 (Petra Christian University, Indonesia)

- The $2^{\text {nd }}$ ASP 2013 (Dongseo University, Korea)

- The $3^{\text {rd }}$ ASP 2014 (University of Malaysia Perlis, Malaysia)

- $\quad$ The $4^{\text {th }}$ ASP 2015 (Josai University, Japan)

- $\quad$ The $5^{\text {th }}$ ASP 2016 (Bangkok University, Thailand)

- $\quad$ The $6^{\text {th }}$ ASP 2017 (Guangdong University of Foreign Studies, China)

In general, the internationalization at Petra Christian University can be categorized into in-bound and out-bound activities or programs, and short or long-term programs. Inbound program is defined as an international activity organized by PCU that is located in Indonesia, while out-bound program can be defined as an international activity carried out in other country/ies.Moreover, a short-term program is described as a non-degree program, while the long-term one is a degree program.

Currently, among the in-bound long-term programs, we have study programs where all subjects are offered in English, namely:

- International Business Management (IBM),

- International Business Accounting (IBAcc),

- International Business Engineering (IBE),

- International Program in Digital Media (IPDM),

- English for Creative Industry Program (English Cravin'), and

- English for Business Program.

Establishing these six study programs that are conducted fully in English provides an opportunity to our Indonesian students to experience an international atmosphere with the presence of foreign lecturers/professorsand/or students. These programs are also the homes for foreign students taking their degrees at PCU or undertaking student exchange program for one semester or more.Students from these program have more opportunities to attend student exchange programs or double/joint degree programs in partner universities abroad.

To provide more opportunities forour students to experienceinternational exposure apart from COP, PCU organizes several in-bound short term programs such as Petra Summer Program, Asia Summer Program in 2012,Surabali (Surabaya and Bali) 2018 Summer Program, and specific tailor-made or service learning programs such as theInternational Construction Study Trip and Work Camp Initiative. We also encourageour students to attend summer programs organized by partner universities, to join student exchange programs, to participate in workshops run jointly by PCU and partner universities in different places, to go for study excursions to industries and other institutions abroad, as well as to do their internships in different countries. To date, approximately 500 of our students have 


\section{AUPF.}

participated in theout-bound international programsyearly.On the other hand, our in-bound international programs accept about 200 international students every year.

To encourage our various academic departments to support our internationalization initiatives, we clearly state our objectives and targets in our Strategic Plan. Each department should base their work plan on this document, where at the end of the financial year it will be internallyaudited. Although there are rooms available for improvement, this strategy seems to work well. Since 2017, our International Office initiated awards, presented to departments with the best performance in in-bound internationalization and out-bound internationalization. The awards were given during our university anniversary celebration.

Associations like Asian Christian Universities and Colleges in Asia (ACUCA) and Asia University President Forum (AUPF) facilitate PCU to expand ourcollaboration with new partners, the new partners which by the time changed to be strategic partners. We believe that having strategic university partners from other countries is really imperative to the success of internationalization. One example from our case is our close tie with Dongseo University (DSU), Busan, Korea. In addition to the success story of our collaboration that resulted in the initiation and growth of our COP, our mutual relationship continues to produce several significant intitatives, such as Asia Summer Program (ASP) that now becomes an official program of AUPF, a double degree program between our English for Creative Industry Program with the Film Department Program of DSU, and a Joint Degree Program in Digital Media. The collaboration also enables our campus to secure a grant from the Korean Government to openKing Sejong Institute in our campus. In fact, werecently also received a grant from Korean industries to have e-Korean class and to install hi-techfacilities for this purpose.

The collaboration with international business companies has played a significant role in providing international internship placements for our students. We also have a combination of student exchange programsand international internships as an added value to our students' internationalization experience. Working hand in hand with our partner institutions and their ties to relevant industries provides this opportunity for us.

Besides collaborating with committed partners, we also collaborate with international institutions that can provide opportunities and funding for our international initiatives. United Board of Christian Higher Education in Asia (UBCHEA) is one of the examples. It enables PCU to conduct international events, to provide international training for our human resources andto provide funding for our faculty members' researchand outreach projects.

Another strategy that PCU does is identifying and maintaining close relationship with alumni who are building their career abroad. One of the examples is a collaboration between our Civil Engineering Departmentwith one of its alumni, who is currently working asa professor in Australia.Every year, he brings his students to join an international program in PCU.

PCU also joins the Forum for International Office in Indonesia since 2015 and chaired the forum in 2017. This forum was established by our Directorate General for Higher Education under the Ministry of Research, Technology and Higher Education. In so doing, PCU always staysin the loop for opportunities provided by our government, such as network, grants opportunities and new regulations related to internationalization in Indonesia.

To give more opportunities for our students to experience internationalization at home, PCU has organizedInternational Day since 2011. It started as a cultural exchange program, and then developed into a comprehensive international event which also incorporated lectures from international professors, all delivered at PCU. The 2018 


\section{AUPF.}

International Day featured eleven (11) lectures delivered by international scholars, involving more than one thousandPCU students. During the event, our international students conducted various cultural classes for our own students and for the community from around the campus.

\section{The Way Forward}

In this era of Industrial Revolution 4.0 and Education 4.0, internationalization in higher education is becoming more imperative. Mutual collaborations with partner universities, institutions, and industries from many different countries willsurely enable us to speed-up the implementation.Mutual collaborations should be established based on respectfulness, mutual benefit and non-discrimination. Consortium should be created to handle several initiatives, such as joint research in certain concentration and other possible programs. Sharing ideas, sharing resources and sharing courses are amongst the possible ways to explore.

In our case, we expect all of our students tobe able to join the international program, either out-bound or in-bound, long-term or short-term, at least once during thecourse of their study atour university. It means that we need to provide more opportunities to approximately 2250 students (or a quarter of the total student body) yearly to actively participate in various international initiatives to gain international perpectives and experience. This target encourages us to have more international strategic partners. 